\title{
Analisis Pengaruh Kepemimpinan, Lingkungan Kerja, dan Motivasi Kerja Terhadap Produktivitas Kerja Karyawan Pada PT Mustika Citra Rasa
}

\author{
Widowati* \\ *Universitas Pamulang. Email : dosen02596@unpam.ac.id
}

\section{ARTICLES INFORMATION}

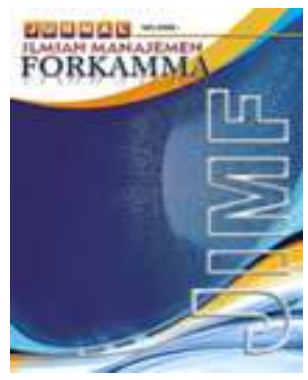

\section{JURNAL ILMIAH MANAJEMEN FORKAMMA}

\author{
Vol.3, No.3, Juli 2020 \\ Halaman: $296-303$ \\ (C) LPPM \& FORKAMMA
}

Prodi Magister Manajemen

UNVERSITAS PAMULANG

$$
\begin{array}{ll}
\text { ISSN (online) } & : 2599-171 X \\
\text { ISSN (print) } & : 2598-9545
\end{array}
$$

Keyword:

Leadership, Work Environment, Work Motivation, Productivity

JEL. classification :

O15,

\section{Contact Author : \\ PRODI \\ MAGISTER MANAJEMEN \& FORKAMMA UNPAM \\ JL.Surya Kencana No.1 Pamulang \\ Tangerang Selatan - Banten \\ Telp. (021) 7412566, Fax (021) 7412491 Email : \\ jurnalforkamma.unpam@gmail.com}

Tujuan penelitian adalah mengetahui pengaruh Kepemimpinan, Lingkungan Kerja, dan Motivasi Kerja terhadap produktivitas kerja karyawan Pada PT. Mustika Citra Rasa. Metode penelitian dengan metode Asosiatif. Sampel sebanyak 110 responden. Teknik analisis data dengan regresi linier berganda. Hasil penelitian: Semakin baik kepemimpinan dalam memberikan arahan, memberikan teladan, dan memberikan rasa semangat pada bawahan maka akan membuat peningkatan produktivitas pada PT.Mustika Citra Rasa. Terbukti dari probabilitas parsial $(0,000<0,05)$. Semakin kondusif, harmonis dan nyaman kondisi lingkungan kerja maka akan membuat peningkatan produktivitas pada PT.Mustika Citra Rasa. Terbukti dari probabilitas parsial $(0,001<0,05)$. Semakin baik motivasi karyawan dalam bekerja maka akan membuat peningkatan produktivitas pada PT.Mustika Citra Rasa. Terbukti dari probabilitas parsial $(0,010<0,05)$. Semakin baik kepemimpinan dalam memberikan arahan, memberikan teladan, dan memberikan rasa semangat pada bawahan, serta Semakin kondusif, harmonis dan nyaman kondisi lingkungan kerja, dan Semakin baik motivasi karyawan dalam bekerja maka akan membuat peningkatan produktivitas pada PT.Mustika Citra Rasa. Terbukti dari probabilitas parsial $(0,000<0,01)$.

The purpose of this study was to determine the effect of leadership, work environment and work motivation on employee productivity at PT. Mustika Citra Rasa. Research methods with the Associative method. Samples were 110 respondents. Data analysis techniques with multiple linear regression. The results of the study: The better leadership in providing direction, setting an example, and giving a sense of encouragement to subordinates will make an increase in productivity at PT.Mustika Citra Rasa. Evidenced by partial probability $(0,000$ $<0.05)$. The more conducive, harmonious and comfortable working environment conditions will make an increase in productivity at PT.Mustika Citra Rasa. Evidenced by partial probability $(0.001<0.05)$. The better the motivation of employees at work, the higher the productivity of PT. Citra Citra Rasa. Evidenced by partial probability $(0.010<0.05)$. The better leadership in providing direction, setting an example, and giving a sense of enthusiasm to subordinates, and the more conducive, harmonious and comfortable working environment conditions, and the better the motivation of employees at work, it will make an increase in productivity at PT.Mustika Citra Rasa. Evidenced by partial probability $(0,000<0.01)$. 


\section{A. PENDAHULUAN}

Penelitian ini dilakukan pada PT Mustika Citra Rasa (Holland Bakery) dimana berdasarkan pengamatan diketahui adanya penurunan produktivitas target yang belum dapat dipenuhi oleh para karywannya. Produktivitas karyawan yang rendah akan membuat dampak yang tidak baik bagi perusahan.

Tabel 1. Data Produktivitas Karyawan

\begin{tabular}{|c|c|c|c|c|c|}
\hline Tahun & $\begin{array}{c}\text { Jumlah } \\
\text { Karyawan }\end{array}$ & $\begin{array}{c}\text { Target } \\
\text { Penjualan } \\
\text { (Rp) }\end{array}$ & $\begin{array}{c}\text { Realisasi } \\
\text { Penjualan } \\
\text { (Rp) }\end{array}$ & $\begin{array}{c}\text { Produktivitas } \\
\text { karyawan (Rp) }\end{array}$ & (\%) \\
\hline 2012 & 124 & 3.000 .000 .000 & 3.359 .000 .00 & 27.088 .710 & $112 \%$ \\
\hline 2013 & 122 & 3.800 .000 .000 & 4.210 .000 .00 & 34.508 .197 & $111 \%$ \\
\hline 2014 & 120 & 4.950 .000 .000 & 5.300 .000 .00 & 44.166 .667 & $107 \%$ \\
\hline 2015 & 118 & 5.150 .000 .000 & 5.110 .033 .00 & 43.305 .364 & $99 \%$ \\
\hline 2016 & 110 & 5.450 .000 .000 & 4.550 .000 .00 & 41.363 .636 & $83 \%$ \\
\hline
\end{tabular}

Sumber: PT Mustika Citra Rasa

Dari data tersebut terlihat bahwa adanya penurunan produktivitas ditandai dengan target penjualan yang tidak selalu tercapai setiap tahun. Selain itu didapati data karyawan yang selama lima tahun juga mengalami penurunan. Penurunan produktivitas tersebut disinyalir atau diduga kuat disebabkan oleh rendahnya kepemimpinan, motivasi dan lingkungan kerja.

Malayu (2016) menyatakan bahwa, "produktivitas tenaga kerja dipengaruhi oleh beberapa faktor-faktor seperti pendidikan, keterampilan, disiplin kerja, budaya, etika kerja, manajemen, tingkat penghasilan, kesempatan berprestasi, beban pekerjaan, budaya organisasi dan teknologi".

Kepemimpinan pada PT. Mustika Citra Rasa produktivitas kerja dari hasil pengamatan peneliti masih belum optimal dikarenakan pimpinan yang jarang secara langsung memantau kegiatan kerja karyawan di toko sehingga tidak dapat menilai secara langsung kinerja karyawan mereka sendiri. Selain itu, lingkungan kerja karyawan masih belum berjalan begitu kondusif, dikarenakan adanya hubungan yang kurang harmonis antar kolega. Seorang dapat bekerja secara profesional jika ia sangat termotivasi. Tetapi kenyataan di lapangan adalah bahwa banyak karyawan yang kurang termotivasi di tempat kerja, sebagaimana dibuktikan oleh perilaku karyawan yang sering absen, sering terlambat dan pergi lebih awal.

\section{Rumusan Masalah}

a. Adakah secara parsial kepemimpinan mempengaruhi produktivitas kerja karyawan pada PT Mustika Citra Rasa.?

b. Adakah secara parsial lingkungan kerja mempengaruhi produktivitas kerja karyawan pada PT Mustika Citra Rasa.?

c. Adakah secara parsial motivasi kerja mempengaruhi produktivitas kerja karyawan pada PT Mustika Citra Rasa.?

d. Adakah secara simultan kepemimpinan, lingkungan kerja dan motivasi kerja mempegaruhi produktivitas kerja karyawan pada PT Mustika Citra Rasa.?

\section{Tujuan Penelitian}

a. Mengetahui adanya pengaruh parsial kepemimpinan terhadap produktivitas kerja karyawan pada PT Mustika Citra Rasa.,

b. Mengetahui adanya pengaruh parsial lingkungan kerja terhadap produktivitas kerja karyawan pada PT Mustika Citra Rasa.,

c. Mengetahui adanya pengaruh parsial motivasi kerja terhadap produktivitas kerja karyawan pada PT Mustika Citra Rasa., 
d. Mengetahui adanya pengaruh simultan kepemimpinan, lingkungan kerja dan motivasi kerja terhadap produktivitas kerja karyawan pada PT Mustika Citra Rasa.,

\section{B. KAJIAN LITERATUR}

\section{Kepemimpinan}

Menurut Siagian (2013:175) "kepemimpinan adalah kemampuan seseorang untuk mempengaruhi orang lain (para bawahannya) sedemikian rupa sehingga orang itu mau melakukan kehendak pemimpin". Menurut Melayu (2010:170) "kepemimpinan adalah proses mempengaruhi orang lain untuk memahami dan setuju tentang apa yang akan dikerjakan dan bagaimana tugas itu dapat dilakukan secara efektif, dan proses memfasilitasi usaha individu dan kelompok untuk mencapai tujuan bersama".

\section{Lingkungan Kerja}

Sukanto \& Indriyo (2000:151) "lingkungan kerja adalah segala sesuatu yang ada disekitar pekerja yang dapat mempengaruhi dalam berkerja meliputi pengaturan penerangan, pengontrolan suara gaduh, pengaturan kebersihan tempat kerja dan pengaturan keamanan tempat kerja". Menurut Alex. N. (2005:25) "lingkungan kerja adalah segala sesuatu yang ada di sekitar para pekerja dan dapat mempengaruhi dirinya dalam menjalankan tugas yang di bebankan".

\section{Motivasi Kerja}

Menurut Prabu (2013:87) "motivasi adalah suatu dorongan dalam diri seseorang untuk melakukan atau mengerjakan suatu kegiatan atau tugas dengan sebaik-baiknya agar mencapai prestasi". Sedangkan Veithzal (2013:176) "motivasi adalah serangkaian sikap dan nilai-nilai yang mempengaruhi individu untuk mencapai hal yang spesifik sesuai dengan tujuan individu".

\section{Produktivitas}

Swastha \& Sukotjo (2007:281) "produktivitas adalah sebuah konsep yang menggambarkan hubungan antara hasil (jumlah barang dan jasa) dengan sumber (jumlah tenaga kerja, modal, tanah, energi, dan sebagainya) yang dipakai untuk menghasilkan hasil tersebut". Menurut Siagian (2013:15) "produktivitas kerja adalah kemampuan memperoleh manfaat sebesar-besarnya dari sarana dan prasarana yang tersedia dengan menghasilkan output yang optimal, kalau mungkin yang maksimal".

\section{Kerangka Berfikir}

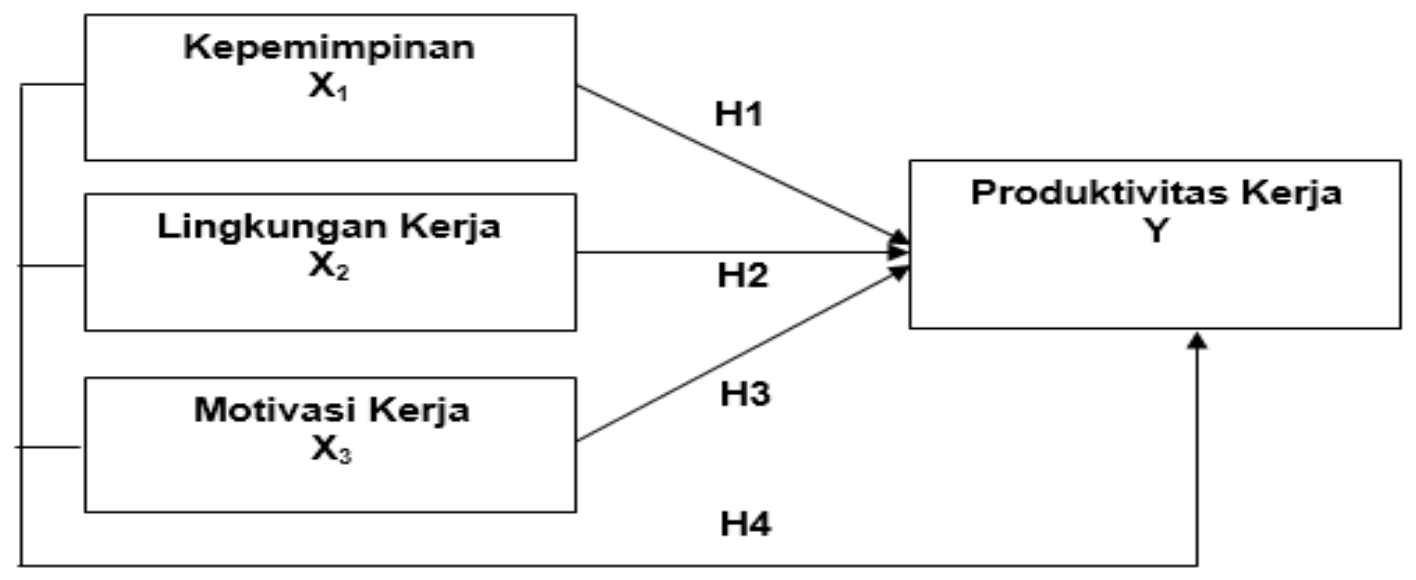

Gambar 1 Kerangka Berfikir 


\section{METODOLOGI PENELITIAN}

Metode Asosiatif digunakan sebagai metode penelitian ini. Sugiyono (2015:44) "penelitian Asosiatif bertujuan untuk mengetahui pengaruh atau hubungan antara dua variabel lebih". Populasinya seluruh karyawan PT Mustika Citra Rasa sebanyak 110 karyawan. "Dalam penelitian ini, teknik sampling yang digunakan adalah nonprobability sampling dengan teknik yang diambil yaitu sampling jenuh (sensus)". (Sugiyono, 2015). Analisis Regresi Linier Berganda digunakan sebagai analisis data.

\section{HASIL DAN PEMBAHASAN}

\section{Uji Instrumen}

Tabel 2 Hasil Uji Validitas

\begin{tabular}{|c|c|c|c|c|c|c|}
\hline Pernyataan & $\begin{array}{c}\text { Nilai } r \\
\text { hitung } \\
\text { X1 }\end{array}$ & $\begin{array}{c}\text { Nilai } r \\
\text { hitung } \\
\text { X2 }\end{array}$ & $\begin{array}{c}\text { Nilai } r \\
\text { hitung } \\
\text { X3 }\end{array}$ & $\begin{array}{c}\text { Nilai } r \\
\text { hitung } \mathrm{Y}\end{array}$ & $\begin{array}{c}\text { Nilai } r \\
\text { tabel }\end{array}$ & Keputusan \\
\hline P1 & 0,609 & 0,609 & 0,469 & 0,293 & 0,187 & Valid \\
\hline P2 & 0,689 & 0,689 & 0,421 & 0,454 & 0,187 & Valid \\
\hline P3 & 0,633 & 0,633 & 0,583 & 0,49 & 0,187 & Valid \\
\hline P4 & 0,694 & 0,694 & 0,56 & 0,524 & 0,187 & Valid \\
\hline P5 & 0,581 & 0,581 & 0,489 & 0,465 & 0,187 & Valid \\
\hline P6 & 0,469 & 0,469 & 0,378 & 0,379 & 0,187 & Valid \\
\hline P7 & 0,429 & 0,429 & 0,451 & 0,538 & 0,187 & Valid \\
\hline P8 & 0,393 & 0,393 & 0,585 & 0,398 & 0,187 & Valid \\
\hline P9 & 0,372 & 0,372 & 0,428 & 0,653 & 0,187 & Valid \\
\hline P10 & 0,283 & 0,283 & 0,526 & 0,627 & 0,187 & Valid \\
\hline P11 & & & & 0,324 & 0,187 & Valid \\
\hline P12 & & & & 0,236 & 0,187 & Valid \\
\hline
\end{tabular}

Sumber: Data diolah penulis (2020)

Dari 42 pernyataan disebar kepada karyawan terlihat bahwa seluruhnya memiliki angka $r$-hitung $>r^{-}$-tabel $(0,187)$ dengan semua item pernyataan valid.

Tabel 3. Hasil Uji Reliabilitas

\begin{tabular}{|l|c|c|c|}
\hline \multicolumn{1}{|c|}{ Variabel } & Nilai Cronbach Alpha & Kriteria & Keputusan \\
\hline Kepemimpinan $\left(\mathrm{X}_{1}\right)$ & 0,709 & $>0,60$ & Reliabel \\
\hline Lingkungan Kerja $\left(\mathrm{X}_{2}\right)$ & 0,689 & $>0,60$ & Reliabel \\
\hline Motivasi Keria $\left(\mathrm{X}_{3}\right)$ & 0,649 & $>0,60$ & Reliabel \\
\hline Produktivitas $(\mathrm{Y})$ & 0,652 & $>0,60$ & Reliabel \\
\hline
\end{tabular}

Sumber: Data diolah penulis (2020)

Tabel 3 diatas menunjukan kriteria reliabel sudah terpenuhi dengan alpha cronbach diatas nilai kritis. 


\section{Uji Asumsi Klasik}

\section{Uji Normalitas}

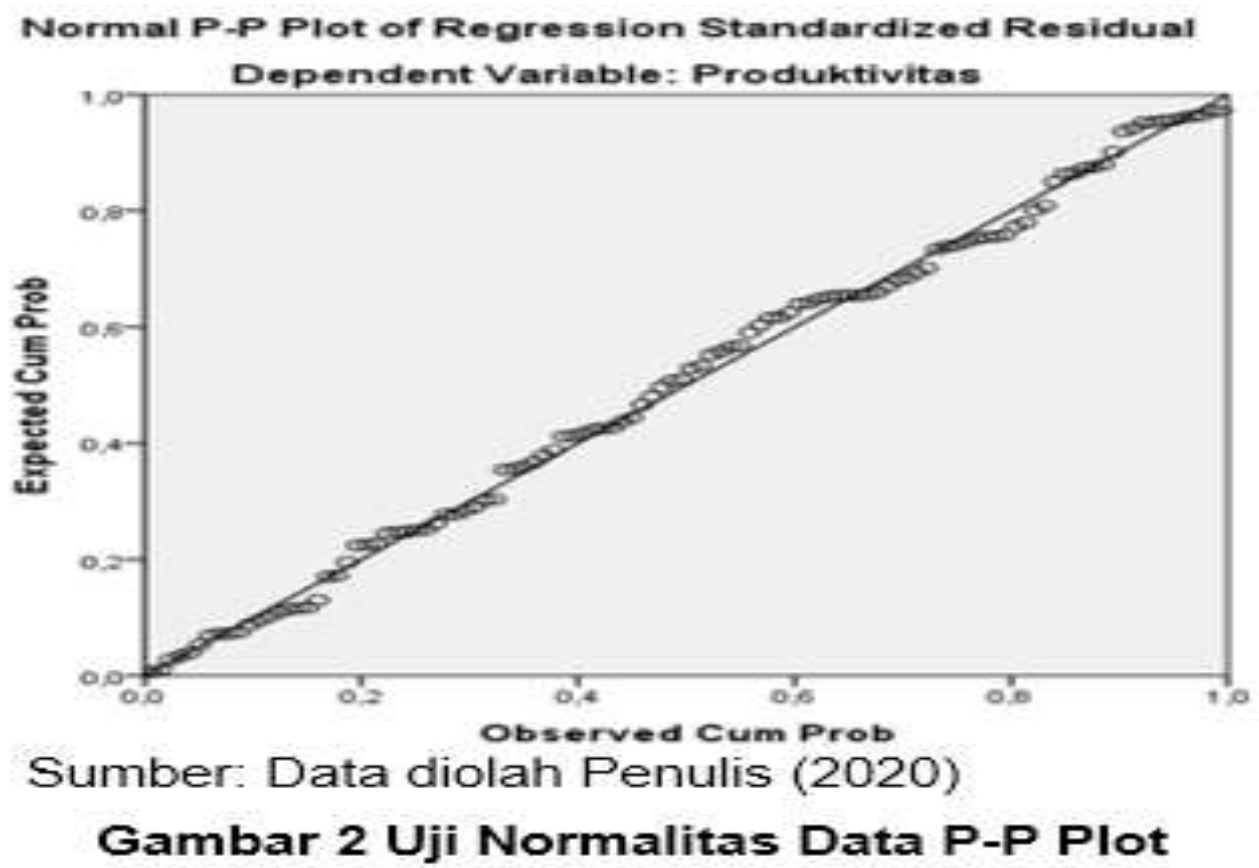

Penyebaran garis terlihat pada Gambar 2 sudah mengikuti garis diagonal dan tidak ada yang melebar jauh, yang merupakan asumsi normalitas sudah dapat dipenuhi

\section{Uji Multikolineritas}

Tabel 4 Uji Multikolinearitas

\begin{tabular}{|ll|r|r|r|r|}
\hline \multirow{2}{*}{ Model } & \multicolumn{4}{|c|}{ Collinearity Statistics } \\
\cline { 2 - 6 } & Tolerance & Kriteria & VIF & Kriteria \\
\hline 1 (Constant) & \multicolumn{3}{|c|}{} & \\
Kepemimpinan &, 976 & $>0,1$ & 1,024 & $<10$ \\
& Lingkungan_Kerja &, 707 & $>0,1$ & 1,415 & $<10$ \\
Motivasi &, 696 & $>0,1$ & 1,437 & $<10$ \\
\hline
\end{tabular}

a. Dependent Variable: Produktivitas

Sumber: Data Diolah penulis (2020)

Pada tabel 4 menunjukan tidak terdapat adanya suatu gejala-gejala yang memungkinkan adanya multikolineritas karena VIF $<10$ dan toleransinya $>0,10$. 


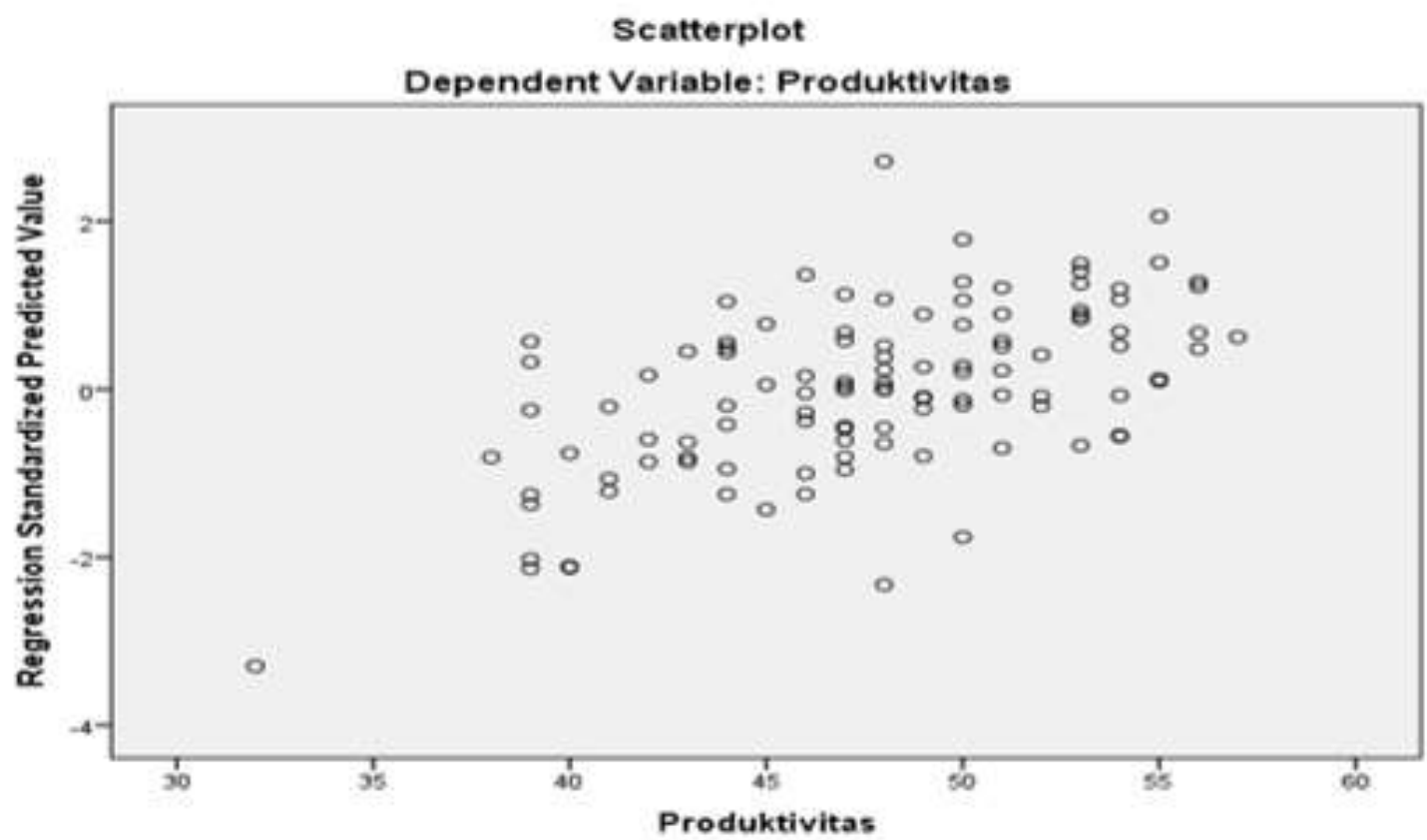

Gambar 3. Pengujian Heteroskedastisitas

Penyebaran data terlihat menyebar secara acak dari bawah maupun dari atas dan tidak ada yang membentuk pola, sehingga data peneitian tidak terjadi heteroskedastisitas.

\section{Uji Regresi Linier Berganda}

Tabel 5. Regresi Linier Berganda

\begin{tabular}{|c|c|c|c|c|c|c|}
\hline & \multirow[t]{2}{*}{ Model } & \multicolumn{2}{|c|}{$\begin{array}{l}\text { Unstandardized } \\
\text { Coefficients }\end{array}$} & $\begin{array}{c}\text { Standardize } \\
\text { d } \\
\text { Coefficients }\end{array}$ & \multirow[t]{2}{*}{$t$} & \multirow[t]{2}{*}{ Sig. } \\
\hline & & $\mathrm{B}$ & Std. Error & Beta & & \\
\hline \multirow[t]{4}{*}{1} & (Constant) & 8,109 & 5,498 & & 1,475 & 143 \\
\hline & Kepemimpinan &, 324 &, 078 &, 332 & 4,138 &, 000 \\
\hline & Lingkungan_Kerja &, 375 & 113 &, 313 & 3,318 &, 001 \\
\hline & Motivasi &, 311 & 119 & 249 & 2,620 & 010 \\
\hline
\end{tabular}

a. Dependent Variable: Produktivitas

Sumber: Data diolah penulis (2020)

$Y=8,109+0.324 X_{1}+0.375 X_{2}+0.311 X_{3}$

1. Nilai constant 8,109 artinya apabila seluruh tiga variabel tidak mengalami peningkatan sama sekali, maka produktivitas karyawan tetap 8,109.

2. Kepemimpinan memperoleh nilai regresi $0,324 \mathrm{X}_{1}$ berarti bahwa pengaruh yang searah yang artinya semakin baik kepemimpinan dalam memberikan arahan maka akan membuat peningkatan produktivitas 0,324 .

3. Lingkungan kerja memperoleh nilai regresi $0,375 \mathrm{X}_{2}$ berarti bahwa pengaruh yang searah yang artinya semakin kondusif dan harmonis kondisi lingkungan kerja maka akan membuat peningkatan produktivitas 0,375 .

4. Motivasi memperoleh nilai regresi $0,311 \mathrm{X}_{2}$ berarti bahwa pengaruh yang searah yang artinya semakin baik motivasi maka akan membuat peningkatan produktivitas 0,311 . 
Uji Koefisien Determinasi

Rsquare

dari

0,335

atau

juga

$33,5 \%$

Tabel 6. Koefisien Determinasi

\begin{tabular}{|l|c|r|r|r|}
\hline Model & $\mathrm{R}$ & $\begin{array}{c}\mathrm{R} \\
\text { Square }\end{array}$ & Adjusted R Square & Std. Error of the Estimate \\
\hline 1 &, $579^{\mathrm{a}}$ &, 335 &, 316 & 4,166 \\
\hline
\end{tabular}

a. Predictors: (Constant), Motivasi, Kepemimpinan, Lingkungan_Kerja

b. Dependent Variable: Produktivitas

Sumber: Data diolah penulis (2020)

adalah

kontribusi dari 3 variabel bebas terhadap produktivitas kerja, sedangkan selebihnya $66,5 \%$ diakibatkan adanya konstruk lain yang tidak termasuk kedalam model ini.

\section{Uji Hipotesis Parsial}

1. Hasil pengujian regresi pada tabel 5 probabilitas $(0,000<0,05)$ menunjukan diterimanya $\mathrm{Ha} 1$ dan ditolaknya $\mathrm{Ho} 1$ yang berarti kepemimpinan berpengaruh parsial terhadap produktivitas pada PT.Mustika Citra Rasa.

2. Hasil pengujian regresi pada tabel 5 probabilitas $(0,001<0,05)$ menunjukan diterimanya $\mathrm{Ha} 2$ dan ditolaknya $\mathrm{Ho} 2$ yang berarti lingkungan kerja mempengaruhi parsial terhadap produktivitas pada PT.Mustika Citra Rasa.

3. Hasil pengujian regresi pada tabel 5 probabilitas $(0,010<0,05)$ menunjukan diterimanya $\mathrm{Ha} 3$ dan ditolaknya $\mathrm{Ho} 3$ yang berarti motivasi berpengaruh parsial terhadap produktivitas pada PT.Mustika Citra Rasa.

\section{Uji Hipotesis Simultan}

\section{Tabel 7. Uji Simultan}

\begin{tabular}{|l|r|r|r|c|c|}
\hline Model & Sum of Squares & \multicolumn{1}{c|}{ df } & Mean Square & $\mathrm{F}$ & Sig. \\
\hline 1 Reqression & 926,021 & 3 & 308,674 & 17,784 & $.000^{\mathrm{b}}$ \\
Residual & 1839,843 & 106 & 17,357 & & \\
Total & 2765,864 & 109 & & & \\
\hline
\end{tabular}

a. Dependent Variable: Produktivitas

b. Predictors: (Constant), Motivasi, Kepemimpinan, Lingkungan_Kerja

Sumber: Data diolah penulis (2020)

Tabel 7 menunjukkan bahwa angka probabilitas lebih kecil dan lebih rendah dari 0,01 atau $(0,000<0,01)$, yang berarti diterimanya $H_{a 4}$ dan ditolaknya $H_{04}$ artinya kepemimpinan, lingkungan kerja, dan motivasi mempengaruhi simultan terhadap produktivitas pada PT.Mustika Citra Rasa. 


\section{E. KESIMPULAN}

1. Semakin baik kepemimpinan dalam memberikan arahan, memberikan teladan, dan memberikan rasa semangat pada bawahan maka akan membuat peningkatan produktivitas pada PT.Mustika Citra Rasa. Terbukti dari probabilitas parsial $(0,000<$ $0,05)$.

2. Semakin kondusif, harmonis dan nyaman kondisi lingkungan kerja maka akan membuat peningkatan produktivitas pada PT.Mustika Citra Rasa. Terbukti dari probabilitas parsial $(0,001<0,05)$.

3. Semakin baik motivasi karyawan dalam bekerja maka akan membuat peningkatan produktivitas pada PT.Mustika Citra Rasa. Terbukti dari probabilitas parsial $(0,010<$ $0,05)$.

4. Semakin baik kepemimpinan dalam memberikan arahan, memberikan teladan, dan memberikan rasa semangat pada bawahan, serta Semakin kondusif, harmonis dan nyaman kondisi ditempat kerja lingkungan, dan Semakin baik motivasi dalam bekerja maka akan membuat peningkatan produktivitas pada PT.Mustika Citra Rasa. Terbukti dari probabilitas parsial $(0,000<0,01)$.

\section{DAFTAR PUSTAKA}

Malayu. H. (2010). "Manajemen Sumber Daya Manusia”. Jakarta: PT Bumi. Aksara.

Mangkunegara, A. P. (2013), "Manajemen Sumber Daya Manusia". Perusahaan. Bandung: PT. Remaja Rosda Karya.

Nitisemito. A.S. (2005). "Manajemen Personalia (Manajemen Sumber Daya. Manusia)". Edisi Kelima, Jakarta: Ghalia Indonesia.

Reksohadiprojo, S., \& Gitosudarmo, I. (2000). "Manajemen Produksi”. Yogyakarta: BPFE UGM.

Sunardi, N., \& Lesmana, R. (2020). Pelaksanaan Alokasi Dana Desa Terhadap Manajemen Keuangan Desa dalam Meningkatkan Efektivitas Program Desa Sejahtera Mandiri Di Desa Cihambulu, Kec. Pabuaran, Kab. Subang. Jurnal SEKURITAS (Saham, Ekonomi, Keuangan dan Investasi), 3(3), 277-288.

Rivai, V., \& Sagala, E. (2013). "Manajemen Sumber Daya Manusia untuk Perusahaan", Jakarta: Rajawali Pers.

Lesmana, R., Sunardi, N., Kartono, K., Rudy, R., \& Sumiaty, R. Y. (2020). Implementasi Manajemen dalam Meningkatkan Minat Baca Warga Desa Cihambulu, Kec. Pabuaran, Kab. Subang, Jawa Barat. Jurnal Abdi Masyarakat Humanis, 1(2).

Lesmana, R. (2017). Pengaruh Citra Perusahaan Terhadap Keputusan Pembelian Konsumen PT. Garuda Indonesia Tbk.(Persero). JIMF (Jurnal IImiah Manajemen Forkamma), 1(1).

Lesmana, R. (2019). Pengaruh Kualitas Produk Dan Kualitas Pelayanan Terhadap Kepuasan Konsumen Pt. Radekatama Piranti Nusa. Jurnal Pemasaran Kompetitif, 2(2), 115-129.

Siagian, S. P. (2013), "Manajemen Sumber daya Manusia”, Jakarta. Bumi aksara.

Sukanto, R., \& Gitosudarmo, I. (2000). "Manajemen Produksi”. Yogyakarta: BPFE UGM.

Swastha, B., \& Ibnu, S. (2007). "Pengantar Bisnis Modern edisi 3". Yogyakarta: Liberty. 